\title{
Theoretical Perspectives of Discursive Phenomena: DA and Ethnomethodologically DA
}

\author{
Indri C. Sihombing \\ Department of English Education, Universitas Lancang Kuning, Indonesia \\ indrichristinan2@gmail.com
}

\begin{abstract}
Received : 2019-06-08
Revised : 2019-06-13

Accepted : 2019-07-10
\end{abstract}

ARTICLE HISTORY

\section{KEYWORDS}

Discourse Analysis

Interaction

Ethnomethodology

\begin{abstract}
The aims of this paper try to discuss and present various theoretical perspectives of discursive phenomena, in specific the different research techniques widely known as, as well as the theories. Having presented the main assumptions of the approach the paper, then discusses and analyze discursive interactions' phenomena, technologically mediated interaction or face-to-face. By concentrating on the pragmatic aspects of discourse, an ethnomethodologically approach of Discourse Analysis (DA), this paper may contribute important ideas and information in media interaction studies.
\end{abstract}

\section{Introduction}

A study of discourse plays a useful role in helping academia to understand the role of many discourse events within the society. The information of Discourse is crucial to complete language's theory. So many definitions of Discourse Analysis from experts. According to Stubbs (1983) said: "Any study which is not dealing with (a) single sentences, (b) contrived by the linguist, (c) out of content, may be called Discourse Analysis". Widdowson (2004) defined Discourse Analysis as the study of language patterns above the sentence and states. Discourse Analysis concerned with language use as a social phenomenon. So, are Discourse only about the method? According to Wood and Kroger (2000) states that Discourse Analysis is not only about method; it is also a perspective on the nature of language and its relationship to central issues of the social sciences. Discourse refers to the linguistics of language use as a way of understanding interactions in a social context, specifically the analysis of occurring connected speech or written discourse, Dakowska (2001) in Hamuddin (2012).

Regarding with the statement by Wood and Kroger, Discourse Analysis is a study that has an answer to questions about language and its relationship; social-interaction, communication. Discourse is derived from discursus (Latin as a noun) or discurrere (Latin as a verb) with the meaning is run back and forth (currere). When discourse is used as the term, a metaphor is built. We might be designating what is the difference between each object of our experience. Sometimes, society cannot notice the metaphorical meaning because we have forgotten the origin. At the same time, people almost use the term text as one of metaphorical expression. While Ethnomethodology is the methods used by people that concerned with procedures and examining methods by members of society.

It should be mentioned that when recalling the etymology we did not purpose at erudition, but at present the metaphorical nature of the term, thereby making it understandable that the context of the object study with this designation stems from its linguistic construction. For these reasons, could define that boundaries separate us from an illusion of naive representation which thinking that researchers can have direct access to reality as if the object of this study is independent of the context achieved by the term used to designate it.

The purpose of this paper is to discuss and present some theoretical perspectives on the understanding the phenomena named discursively, especially the ones tending to be identified, occasionally under the generic term of discourse analysis or under the ethnomethodologically approach to discourse. After presenting some aspects of these approaches, we discuss its potential to analytically explore discursive interaction's phenomena, both face to face and in media environments. By concentrating on the interactional aspects and pragmatic of discursive phenomena, the ethnomethodologically discourse may represent something important to the media interactions studies.

In addition, some contributions from various approaches are illustrated and explained with data collected from fieldwork conducted in digital media environments (Braga, 2008). To prevent misunderstandings, we remember that the discourses generated in the digital environment have the 
advantage, on the one hand, comes from the media and, in another one, shows, through its studies, the diverse nature of its interactions. Regardless of its specificity, the discourse generated in the digital media environment mobilizes an important part of the conversation tools people use in their spontaneous interactions.

\section{Method}

There are several definitions for discourse according to Schiffrin, Tannen, and Hamilton (2003) in The Handbook of Discourse Analysis, the paper believes it should be better to re-group onto 3 groups as the following:

The first consists of definitions that are usually proposed by linguists with structuralism as the inspiration. Accordingly, discourse is a natural language expression sequence consisting of two or more clauses or phrases. Its means language is an organized expressive unitary system that has an independent meaning of its usage and makes possible signification of what the speaker says. When approaching discourse, the aims of the authors of this conception is to investigate how people apply the system of the linguistic that is innate to humankind; which process the system of linguistic so that the discourse is coherent and cohesive; and how human use it when referring to the world. Thus, the essentials of this approach are the referential processes as well as the mechanisms that guarantee coherence and cohesion to the text.

The second is considered by writers who have a concept of pragmatic language: discourse is made by the human from natural language. Given that the authors of this conception embrace the pragmatic approach, the most studied issues in this context are also focused on this topic, especially with regard to the study of reference modalities, to the study of speech acts, to the process of cognitive involved in the constitution of meaning, with the special superiority to study the presuppositions and the implicit primarily of the importance of prejudice of speech, as long as it is not speech, but agreement on what they consider important that allows the formation of agreement and disagreement, and the debate focusing what the utterance state.

And the last one is the combination of three definitions by social scientist, especially by scholars of communication, thinking that discourse is an expression or manifestation, verbal or nonverbal of a social practice. The authors who adopt this approach usually deal with the scientific discourse, for example, to refer to urban municipal planning, pictorial discourse (Kruger, 2005), to designate an imageshaped organization of the era, from the style or work of the painter.
Each of these definitions stem from certain theoretical preconceptions and, therefore, not only delimits objects of observation, but also deals with some problems and follows particular paths of investigation. It also means that discourse is an interdisciplinary object that even within the subject can be approached from a different perspective.

Approaches related to the second and third perspectives, regardless of their differences, present some common characteristics of discourse. Firstly, discourse is an activity that produces the effect. Secondly, discourse builds a world of experience. Thirdly, discourse does speech acts, such as questions, invitations, statements, requests, orders, greetings and the last, discourse analysis consistent with its inventorying, identification and systematic explanation of how they are structured.

\section{Result and Discussion}

\subsection{Discourse: The Ethnomethodological Approach}

The ethnomethodologically approach a phenomenological basis, by concentrating on a movement of going back to the things themselves and the consequences will of the researcher, movement that Edmund Husserl elected the Greek term epoche, and similar to the second and third philosophies of discourse, a pragmatic inspiration, by distinguishing itself from the structuralize notions of language.

As the expression ethnomethodology may incorrectly indicate that it is a study methodology, we would like to simplify its meaning. Ethnomethodology is not unerringly a theory or a school, but a definite attitude or an approach of facing social reality, which first appeared in the late 1930s and spread later, mainly from the 1970 s, to other regions.

So, ethnomethodology concentrations in the study of significance that agents and social actors attribute to their own social practice, breaking, thus, with tendencies that consider the significance those inhabitants attribute to their action as just a malformed reflex of the structural fortitude of the social system.

The core characteristics of the ethnomethodologically approach to discourse are the significance of discourse is a social activity at each of the interactional conditions established among them locally of daily life; In the interactions of discursive in which they are required, people organize knowledge and reconstruct their own world; When people talk, they do interactional acts; Discourse is a unit that involves more than a participant; The units of discourse are expressions that can be constituted by verbal entities, intonation, by mimic-gestural and also by silencing; The discursive activity is commanded and regulated. 


\subsection{Discourse: Rules of Interaction}

\subsubsection{The devices in Turn Taking}

Many authors of ethnomethodological dedicate most of their work to learning curves, especially turn taking; they know that The participants make rules and obey the rules in order to understand when it time to speak or listen to prevent misunderstanding. Thereby preventing two phenomena susceptible to harm. The interaction itself: overlapping long speeches and long hiatuses between speeches.

\subsubsection{The Fixing Phenomena}

Fixed error phenomenon is a very common domain in the ethnomethodological study of verbal communications, which distinguishes cases in which mistakes are pointed out and/or corrected by the speakers. Their very interesting counterpart is the fact that, initially, the participants showed a preference for the cases in which the people signaled and corrected their mistakes. This preferential organizational phenomenon, however, is more common, as it regulates other interactional devices, as a couple's organization of proximity.

\subsubsection{The Parts of Interactional: The Adjacentt Pairs}

Ethnomethodology is the adjacentt pairs that form the dialogic units of discursive interaction. The concept of preference is a logical concept, which is connected to what is preferred by the discursive communication society itself. When formulating the first pair and the two pair of adjacent, people. It is important to emphasize the notion of preference rather than ideological, which is related to what the discursive interaction organization likes it. Overall, people, when generating preferential intervention, are full without hiatus, hesitation or justification, while when generating non-preferential intervention, do so after a transferable gap. "You know", "um", and the non-preferential act of their intervention.

\subsubsection{The Involvement Strategy}

Involvement is a facilitator of discursive interaction, making the connection and also facilitates the agreement among them. The involvement of discursive is the process responsible for the explanation of expressive states which is a part of esthetic aspects of verbal interaction. The positive effect of involvement is when it contributes to the increase of the relationships among participants and the negative one is when it provoked a disagreement among them. We can differentiate three involvement's modalities: interpersonal involvement, self-involvement and involvement with which discourse of handling (Tannen, 2007).

\section{Conclusion}

The approach of ethno methodological observes what people make when communicating or interacting each other by using language resources. Ethnomethodology continues to seek to criticize its own viewpoint; to interfere at least as it does in observed phenomena; to fight against a tendency to project the world views of researchers in the observed world.

This approach to consist in a perception of the study of discourses contrasting to the discourse analyses that seek to denounce, criticize and identify the discourses of others, once it is a critical attitude of the discourse of the researcher him/herself, in order to make him/her available to become amazed for the inexhaustible wealth of the discursive activity of human beings.

Moreover, the importance of the ethnomethodologically approach to discourse is to show briefly, about some of the regularities of the discursive activity to find out, its complementary compared to the different modalities of discourse analysis through the description.

\section{Acknowledgement}

This research was supported/partially supported by Dept. of English Education, FKIP Universitas Lancang Kuning. We thank our colleagues who provided insight and expertise that greatly assisted the research, although they may not agree with all of the interpretations/conclusions of this paper.

\section{References}

Dakowska, M. (2001). Psycholingwistyczne podstawy dydaktyki języków obcych. Wydawn. Nauk. PWN.

Garfinkel, H. (1996). Studies in Ethnomethodology. Cambridge: Polity Press

Hamuddin, B. (2012). A Comparative Study of Politeness Strategies in Economic Journals. Doctoral dissertation, University of Malaya

Hamuddin, B. (2015). DISCOURSE ON MEDIA: Bringing Hot News into ELT's Classroom Discussion. Proceedings of ISELT FBS Universitas Negeri Padang, 3, 87-95.

Hamuddin, B., \& Noor, F. N. M. (2015, August). A Closer Look on Politeness Strategies in Malaysian Economic Journal. In 2nd INTERNATIONAL SEMINAR ON LINGUISTICS (p. 52).

Harding, J. (2018). Qualitative data analysis: From start to finish. SAGE Publications Limited.

Johnstone, B. (2018). Discourse analysis. John Wiley $\&$ Sons.

Jones, R. H. (2012). Discourse analysis: A resource book for students. New York, NY. 
KhosraviNik, M. (2015). Discourse, Identity and Legitimacy. John Benjamins.

Krippendorff, K. (2018). Content analysis: An introduction to its methodology. Sage publications.

Lucke, A. (1996). Text and Discourse Analysis. New York: American Educational Research Association. Vol. 21:3-17.

Maxwell, J. A. (2010). Essay Review of Jean Anyon's Theory and Educational Research: Toward Critical Social Explanation. Education Review//Reseñas Educativas.

McGregor, S.L.T. (2010). Critical Discourse Analysis: A Primer. Halifax. Mount Saint Vincent University

Morgan, A. (2010). Discourse analysis: An overview for the neophyte researcher. Journal of Health and Social Care Improvement, 1(May), 1-7.

Okot, M.B. (2007). Text and Textuality in Oral Performance. London. Sage Publications.

Olson, B. (2007). Quantitative "versus” Qualitative Research: The Wrong Question. Edmonton. University of Alberta Press.

Rodrigues. A. D., \& Braga, A. A. (2014). Discourse Analysis and Ethnomethodological Discourse Analysis. MATRIZes, 8(2), 117-134.

Rogers, R. (2017). Critical discourse analysis in education. Discourse and education, 41-54.

Rogers, R., Malancharuvil-Berkes, E., Mosley, M., Hui, D., \& Joseph, G. O. G. (2005). Critical discourse analysis in education: A review of the literature. Review of educational research, 75(3), 365-416.

Sari, R., Putri, S. E., Herdi, H., \& Hamuddin, B. (2018). Bridging critical discourse analysis in media discourse studies. Indonesian EFL Journal, 4(2), 80-89.

Schiffrin, D., Tannen, D. \& Hamilton, H. E. (2003). The Handbook of Discourse Analysis. Malden. Oxford: Victoria, Blackwell Publishing

Stubbs, M. (1983). Discourse analysis: The sociolinguistic analysis of natural language (Vol. 4). University of Chicago Press.

Suppes, P. (1974). The place of theory in educational research. Educational researcher, 3(6), 3-10.

Van Dijk, T. A. (2006). Ideology and discourse analysis. Journal of political ideologies, 11(2), 115-140.

Wood, L. A., \& Kroger, R. O. (2000). Doing discourse analysis: Methods for studying action in talk and text. Sage. 